\title{
MeAsures INTROducEd IN THE SlovaK Republic in Response to THE Public Health CRISIS CAUSED BY THE COVID-19 PANDEMIC
}

Accepted
31. 07. 2021
Revised
19. 08. 2021
Published
29. 10. 2021

Keywords

emergency situation, right to health, transmissible diseases, criminal liability, rule of law

\section{Silvia Capíková, ${ }^{1}$ Eduard Burda ${ }^{2}$ \& Mária Nováková ${ }^{2}$}

${ }^{1}$ Comenius University in Bratislava, Faculty of Medicine, Bratislava, Slovakia.

E-mail: silvia.capikova@fmed.uniba.sk

${ }^{2}$ University in Bratislava, Faculty of Law, Bratislava, Slovakia.

E-mail: eduard.burda@flaw.uniba.sk,maria.novakova@flaw.uniba.sk

CORRESPONDING AUTHOR

silvia.capikova@fmed.uniba.sk

Abstract The SARS-Cov-2 pandemic outbreak in the Slovak Republic in March 2020 required rapid legal response to protect lives and health of inhabitants and new complex challenges emerged. The objective of this paper is an analysis and critical assessment of measures adopted in the field of health law. As most significant problem fields in Slovakia arose: 1/ Legality and hierarchy of measures limiting everyday life and exercise of citizen rights and freedoms; 2 / the scope, proportionality, extent and duration of measures; 3 / adherence to the measures by the public and law enforcement issues. The pandemic unraveled need to innovate the legal framework of contagious diseases control, for example, constitutional emergency regimen, or powers of the Public Health Authority. Established rule of law framework served to safeguarding against some disproportionate or unwanted effects of antipandemic measures, however, future development of more sophisticated legal tools to control the pandemic is needed. 


\section{$1 \quad$ Introduction}

COVID-19 is a communicable disease, caused by severe acute respiratory syndrome coronavirus 2 (SARS-CoV-2) that was declared a pandemic by the World Health Organization on March 11, 2020. The novel disease was named COVID-19 on February 11, 2020 by WHO (WHO, 2020). In March 2020, the COVID-19 disease, how it spread, its lethality and impact on human health, its diagnostics and treatment, were imponderables and all countries worldwide have been fighting to contain it since then. What was generally recommended by WHO experts to prevent mass spreading of the COVID-19 disease and hamper death rates was isolation of those confirmed to be infected and those suspected of being infected (quarantine), reduction of frequency of interpersonal face-to-face contacts, disinfection of surfaces, hand hygiene and disinfection, and wearing face masks to reduce inhalation of aerosol from breathing.

The first patient in the Slovak Republic (hereinafter: SR) was hospitalized with COVID-19 disease on March 6, 2020. The Government declared an emergency situation under the State Security Act (2002) on March 15, 2000. The emergency situation was approved by the Parliament, and lasted 45 days until Jun 13, 2020. Because of an incidence and mortality surge, the emergency situation due to COVID-19 was declared again by the Government on September 30, 2020 and repeatedly prolonged. An extraordinary situation related to COVID-19 in Slovakia was announced under the Act on Civil Protection (1994) by the Government Resolution No. 111 of March 11, 2020, valid since March 12.

Due to the pandemic, law became an increasingly visible tool of public health, with a myriad of measures passed to enable disease control. The aim of our paper is to describe, analyze and critically assess the legal framework in Slovakia and the legal remedies enacted to combat COVID-19, emphasizing those in force between March 12, 2020 and March 15, 2021. We applied various methods of legal research to identify key changes in the regulatory landscape, such as the descriptive method, analysis, synthesis comparison and abstraction. The main focus of the paper is directed toward the SR's regulatory response to the public health crisis caused by the pandemic. Antipandemic measures were adopted through the enactment of various types of normative legal acts. Thus, our research focused on the lawmaking activity of various state authorities. We include a comparison analysis of basic legal 
framework vs constitutional framework to control contagious diseases, including from the criminal law perspective. We examined the rule of law conceptual framework to help better understand problems related to the legal response to the COVID-19 pandemic, with national regulation in the SR as a case study to examine how the existing legal framework of a democratic country responded to the need to control the spreading of an unknown, lethal contagious disease.

\section{SARS-Cov-2 as a Public Health Threat}

Since the fall of the iron curtain in 1989, the national health system and its financing shifted slowly from the Semashko to the Bismarckian model. (Chandogová, 2018: 108) The national legal system is based on Roman legal tradition and statutory law. Ariticle 40 of the Constitution of the SR (Act No. 460/1992 coll.) stipulates that the right to health is a human right, and that the right to health care shall be free of charge under conditions defined further by national legislation. For decades, a robust system of regional health offices had been built as the backbone of preventive interventions in the field of public health.

\subsection{System of public health protection}

The Public Health Act (hereinafter: PHA) (2007) comprehensively addresses issues of health protection against physical, chemical and biological environmental factors, especially arising out of the working environment, broadly regulates the prevention of communicable and non-communicable diseases, including occupational health services or assessment of health fitness for work and surveillance of dietary supplements. The PHA further regulates reporting duties and surveillance of defined diseases and measures. Pubic heath bodies have extensive control powers and can impose administrative sanctions for breach of mandatory duties and can issue decisions and order measures. The Ministry of Health of the SR (hereinafter: MHSR) issued several by-laws to implement the provisions of this Act (e. g., the Decree of MHSR No. 585/2008 Coll.), followed by guidelines of the MHSR of a technicalorganizational nature. Ordinance of the Government No. 395/2006 Coll. "on minimal requirements on provision and use of personal protective equipment at work" is a constituent element of the legal framework of preventing contagion. 
Public health is defined by the PHA as "the level of health of society, which corresponds to the level of provided healthcare, health protection and support and the economic level of society". The purpose of the Act is the protection, promotion and development of public health, which is a legitimate aim for the adoption of measures that may interfere with rights and freedoms.

Responsibility for public health at the central level is divided between the Ministries of Health, Defense, Home Affairs and Transport and one central body called the Public Health Authority of the Slovak Republic [hereinafter PHASR] covering up to 36 regional offices, which have historically developed from a system of hygienic stations, established in the period of existence of the Czechoslovak Socialist Republic. PHASR is a budgetary organization at the MHSR, established by the Act No. 355/2007 Coll. One of the bodies of the PHASR is the national anti-epidemic committee and several regional anti-epidemic committees, composed of experts. As advisory bodies, their role is constrained to proposing preventive measures.

\subsection{Concept of a threat to public health}

Under $₫ 48$ par. 1 of the PHA, the threat to public health occurs upon:

"(a) occurrence of a communicable disease, suspicion of a communicable disease or suspicion of death of a communicable disease above the expected level,

(b) release of chemical substances endangering life, health, environment and property or

(c) leakage of microorganisms or toxins from enclosed spaces".

The Covid-19 pandemic poses a threat to public health under point (a). When public health is endangered, PHASR or the regional public health authority have relatively broad competencies. Under $\ 48$ par. 4 of the PHA (2007) either the "PHASR or a regional public health authority may order measures which are:

a) hygienic cleaning of people and decontamination of terrain, buildings, materials and means of transport;

b) a ban on the production, treatment, storage, transport, import, sale and other handling of items that may spread diseases to humans, or an order for their disposal; 
c) prohibition or restriction of contact of a part of the population with the rest of the population in the event of a mass outbreak of a serious disease;

d) prohibition or restriction of mass events;

e) a ban or restriction on the operation of facilities where people are gathered;

f) banning the use of water and objects suspected of being contaminated and regulating water consumption;

g) a ban on the use of food, meals or beverages in mass caterers;

h) placing warning signs on objects, if they are subject to measures under letters a) to g);

i) prophylaxis;

j) special regime of operation of collective facilities;

k) collection and transport of biological material;

l) dispensation and use of special personal protective equipment;

m) safe disposal of contaminated material;

n) forced isolation of persons suffering from a communicable disease who refuse the ordered measure;

o) disinfection and control of animal pests;

p) allocation of beds to provide institutional healthcare to the increased number of patients and in case of serious infections to ensure the isolation of persons suspected of having the disease and suspected of infection during the maximum incubation period of the disease;

q) special handling of the dead, allocation of places and determination of the method of burial of the increased number of deaths".

\subsection{Emergency event vs. extraordinary event under the Public Health Act}

The PHA, as amended, recognizes the "threat to public health of 2nd degree" in accordance with the International Health Regulations, which represents a higher degree of threat requiring implementation of the procedure under the Act No. 42/1994 Coll. Act No. 42/1994 Coll. on civil protection of the population defines an emergency situation as "a period of threat or effect of the consequences of an extraordinary event on life, health or property, which is declared pursuant to this Act". An emergency situation is the result of an emergency event. An extraordinary event is, for example, a natural disaster, an accident, but also a threat to public health of 2 nd degree, i.e. if a communicable disease occurs, if there is suspicion of a communicable disease or death of a communicable disease "above the expected 
level". An extraordinary situation is declared and revoked by the Government of the Slovak Republic [hereinafter Government] if the extent of the endangered or affected area exceeds the territorial district of the region. If the scope of the extraordinary event concerns only the territorial district of the region, the District Office in the seat of the region declares and recalls the extraordinary situation in the territory of the given region. In the event of an emergency on the territory of the municipality, the municipality declares and revokes the emergency situation. The declaration and recall of an emergency situation are carried out through the mass information resources. During an emergency, measures are taken to save lives, health or property, and to reduce the risks of hazards or actions necessary to prevent the spread and effects of the emergency.

The competence of the PHASR to issue measures under $\ 48$ par. 4 of the PHA is possible in the case of a situation beyond the territory of the regional public health authority, but the Act does not indicate that the PHASR has competence even in the case of a pandemic (national) threat to public health reaching the intensity of an emergency or a state of emergency affecting all persons in the territory of the state. A contrary interpretation could be in conflict with not only the constitutional principles of restricting fundamental rights and freedoms, but also with the principle of separation of powers and the rule of law (Vernarec \& Piešt'anský, 2020). By its measures, the PHASR often interferes with fundamental rights and freedoms areawide, without territorial or temporal limitation or delimitation, for example, Measure of the Public Health Authority in Case of Public Health Threat No. OLP/5453/2020, introduced since March 24, 2020, a ban on movement of persons in an interior of buildings without coverage of mouth and nose by protective equipment such as a facemask, shawl or scarf.

\section{Emergency status in response to a COVID-19 pandemic}

In the exhaustively determined situations, the Constitutional Act No. 227/2002 Coll. on the security of state at times of war, state of war, extraordinary state and state of emergency, as amended (hereinafter referred to as the "State Security Act") allows the Government to restrict the personal freedoms of Slovak citizens, distinguishing between both extraordinary state and state of emergency. 


\subsection{Extraordinary state and a state of emergency}

Article 1, par. 2 of the said Act explicitly states that the basic task of public authority, even in times of emergency, is the observance of fundamental rights and freedoms. Article 2 of the Constitution of the Slovak Republic (hereinafter: Constitution) (1992) stipulates that "state bodies may only act on the basis of the Constitution, within its limits and to the extent and in the manner provided by law". This applies to a wide range of human and civil rights, the restriction of which was required by measures proposed by public health professionals, for example, restriction of freedom of movement by prohibition of entry into certain establishments, curfew, prohibition of travel outside the district of permanent residence, quarantine of persons coming from abroad, etc.

Article 1, par. 4 of the said Act defines a crisis situation as "a period during which the security of state is immediately endangered or disturbed and the constitutional authorities may, after meeting the conditions laid down in this constitutional act to resolve it, declare war, and declare a state of war or extraordinary state or state of emergency." In the COVID-19 pandemic situation it was only possible to use the emergency state.

Article 17 of the Constitution stipulates that personal liberty is guaranteed and no one may be deprived of his liberty other than for reasons and in the manner provided by law. Among other things, in the case of accused and suspected criminal offenses, these persons may be detained only in cases stipulated by law, the accused must be made acquainted with the reasons for detention and a judge must decide on their detention within 48 hours at the latest. This follows from both the Constitution and the provisions of $\int 87$ par. 2 of the Criminal Procedure Code (the Act No. 301/2005 Coll.).

The President is entitled to declare the extraordinary state within the meaning of Article 4 of the State Security Act assuming several conditions are met. 1) The Government submits a motion to declare a state of emergency. 2) The conditions that must be met to justify granting the motion are that "a terrorist attack either has taken place or is imminent; the existence of large-scale street riots linked to attacks on public authorities; the existence of the looting of shops and warehouses or other mass attacks on property, or other massive violent acts which in their scope or 
consequences substantially endanger or disturb public order and the security of state; such attack cannot be averted by the action of public authorities and the effective use of legal means is prevented. An extraordinary state can only be declared in the affected or an imminent territory." 3) "The extraordinary state can be declared to the necessary extent and time, for a maximum of 60 days. If new circumstances arise directly related to the reasons for which the extraordinary state initially was declared, then the extraordinary state may be extended to the extent and for the time necessary, for a maximum of 30 days".

On the other hand, the Government may declare a state of emergency within the meaning of Article 5 of the Act if the following conditions are met: 1 ) there was or is an imminent threat to human life and health, even in a causal connection with a pandemic, environment or significant property values due to a natural disaster, catastrophe, industrial, traffic or other operational accident; 2) a state of emergency can only be declared in the affected or in imminently endangered area. 3) The Government is obliged to specify to what extent and for what necessary time it declares a state of emergency, while the time may not exceed 90 days. 4) The declaration and the end of emergency must be announced in the press, on the radio and television and in the Collection of Laws of the Slovak Republic. The said conditions became subject of amendment in December 2020.

According to Škrobák (2020), there are several differences between an extraordinary state and a state of emergency, the "most fundamental concerning the nature of the crisis situation to which a particular constitutional regime responds - in the case of extraordinary state it is a danger having the nature of attacks by people or groups of people on protected interests, while in a state of emergency it is a constitutional regime which responds to a danger having the nature of force majeure or a danger which is not caused by intentional unlawful conduct of certain persons, or groups of people." 


\subsection{Changes of emergency regimen introduced due to the pandemic}

Until December 29, 2020, pursuant to Article 5, paragraph 3 of the State Security Act (2002), the Act stipulated that "in times of emergency, fundamental rights and freedoms may be restricted to the extent and for the time necessary according to the seriousness of the threat and obligations imposed in the affected or immediately endangered territory, at most to the following extent:

a) to limit the inviolability of the person and his privacy by evacuation to a designated place;

b) to impose work duties to ensure the supply, maintenance of roads and railways, the operation of transport, the operation of water supply and sewerage, the production and distribution of electricity, gas and heat, the performance of healthcare, the maintenance of public order or the elimination of damage incurred;

c) to limit the exercise of ownership of real estate for the deployment of soldiers, members of the armed forces, medical facilities, supply facilities, rescue services, and release and other technical facilities;

d) to restrict the exercise of ownership of movable property by prohibiting the entry of motor vehicles or restricting their use for private and business purposes;

e) to limit the inviolability of the dwelling to the accommodation of evacuees;

f) to restrict the delivery of postal items;

g) to restrict freedom of movement and stay by curfew at a specified time and a ban on entry into the affected or directly endangered territory;

h) to restrict or prohibit the exercise of the right to peaceful assembly or make assembly in public conditional on authorization;

i) to restrict the right to disseminate information freely, regardless of borders, and freedom of expression in public;

j) to ensure access to radio and television broadcasting associated with calls and information for the population;

k) to prohibit the exercise of the right to strike;

l) to take measures to address the state of oil emergencies." 
On December 28, 2020 the Parliament adopted the Constitutional Act No. 414/2020 Coll. amending the State Security Act. The amendment was effective December 29, 2020. The amendment explicitly defined that a state of emergency and an extraordinary state can also be declared in the entire territory of the SR. It introduced the possibility of prolonging the state of emergency, but only if it was declared because of a threat to life and health of persons in the causal connection with the pandemic, and then only to the extent and for the time necessary, for a maximum of another 40 days, even repeatedly. The extension of the state of emergency must be approved by the Parliament within 20 days from the first day of the extended state of emergency. In the event that the Parliament does not render its consent, the extended state of emergency shall expire on the day of non-approval of the Government's proposal to express consent to the extension of the state of emergency, or upon expiry of the period for expressing such consent. The approval is also required in the case of a re-declaration of a state of emergency, if 90 days have not elapsed since the end of the previous state of emergency declared for the same reasons. Parliamentary oversight includes a set of tools to hold the Government accountable, one of which is the duty of the ministry or institution concerned to provide Parliament with information on the measures adopted.

The amendment also modified the scope of the restrictions of fundamental rights and freedoms, depending on whether the state of emergency was declared due to endangerment of life and health of persons in causal connection with the pandemic, in which case the scope is defined by a new paragraph 4; otherwise, the scope of rights may be more significantly limited in line with the wording of the innovated paragraph 3.

Since December 29, 2020, Article 5, new paragraph 4, provides that "at the time of a state of emergency declared for reasons endangering life and health of persons causally related to a pandemic, fundamental rights and freedoms may be restricted to the extent and for the time necessary; to impose obligations on the affected or on the imminently endangered territory, which may also be the entire territory of the SR, at most to the extent pursuant to paragraph 3 letter a), b), e), g), h) or j)." In particular, it is only possible to:

- "limit the inviolability of the person and his privacy by forced stay in a dwelling or by evacuation to a designated place" (Article 5, par. 3, letter a)); 
- cimpose a duty of employment to ensure the supply, maintenance of roads and railways, the operation of transport, the operation of water supply and sewerage, the production and distribution of electricity, gas and heat, the performance of healthcare or the maintenance of public order (Article 5, par. 3, letter b));

- "prohibit the entry of motor vehicles or restrict their use for private and business purposes" (Article 5, par. 3, letter e));

- "restrict the delivery of postal items" (Article 5, par. 3, letter g));

- "'"restrict freedom of movement and residence by a curfew at specified times (Article 5, par. 3, letter h));

- "restrict the right to disseminate information freely regardless of national borders and freedom of expression in public" (Article 5, par. 3, letter j)).

\subsection{Powers of highest state bodies under the State Security Act}

The highest state bodies also operate differently during the extraordinary state. The Government of the Slovak Republic has a strengthened position, which in times of a state of emergency has the power not only to restrict individual freedoms to the extent defined by the Constitutional Act on State Security, but also to issue temporary legal norms (government resolutions) that are effective even without parliamentary consent. The Parliament has the power to pass laws in an abbreviated legislative procedure - so practically any parliament can pass any law, not just a law that applies to the resolution of situations arising from or related to the circumstances that led to the declaration of a state of emergency.

Pursuant to Article 6, par. 2, letter a) - b) of the Constitutional Act on State Security (2002), the Government is responsible for the defense and the security of the state and is obligated to determine the basic concept of defense and security of state. "The security is a state in which the peace and security of state, its democratic order and sovereignty, territorial integrity and the inviolability of state borders, fundamental rights and freedoms are preserved and the lives and health of persons, property and environment protected." (2002, Article 1 par. 2). 
Pursuant to Article 6, par. 2, subpar. c) - h), the Government also has other defined competencies:

- "to organize the preparation of constitutional bodies for the time of war, state of war and extraordinary state;

- to organize the preparation of economy, supply of population and state material reserves for time of war, state of war and extraordinary state;

- to organize the preparation of regions and the preparation of districts in the territorial district of the district office for the time of war, state of war, extraordinary state and state of emergency,

- to take measures to mitigate and remedy the damage and other consequences caused for the time of war, state of war, extraordinary state and state of emergency;

- to coordinate the activities of the armed forces, the Fire and Rescue Corps and the rescue services for the time of war, state of war and extraordinary state;

- on the proposal of the Security Council of the SR, to determine the amount of stocks of basic commodities for maintaining the security and defense of state and the method of financial security for the performance of tasks related to time of war, state of war, extraordinary state and state of emergency".

State of emergency under the Constitutional Act No. 227/2002 Coll. on State Security, as amended, also allows public authorities to impose obligations on natural and legal persons under the Act No. 179/2011 Coll. on Economic Mobilization, as amended.

State authorities are bound by the Act No. 45/2011 Coll. on Critical Infrastructure, as amended, which defines the elements of critical infrastructure and determines the obligations of their operators and the competencies of state administration bodies in their protection. Pursuant to $\ 2$ par. (a) critical infrastructure element means "in particular civil engineering, the public service and the information system in the critical infrastructure sector, the disruption or destruction of which, according to sectoral and cross-cutting criteria, would have serious adverse consequences for the state's economic and social function, and thus for the quality of life of the population 
in terms of the protection of their lives, health, safety, property and the environment".

\subsection{Regulatory activity of the Government}

In a short time, the Government adopted resolutions, published in the Collection of Laws of the SR under numbers 45/2020 Coll., 49/2020 Coll., 64/2020 Coll., 72/2020 Coll. and 84/2020 Coll. The above-mentioned resolutions (apart from Resolution No. 72/2020) apply to both healthcare and social service providers and to the prohibition of exercising their right to strike.

On March 15, 2020, the Government by its resolution No. 114 (published as No. 45/2020 Coll.), declared a state of emergency, which concerned only the territorial districts of 12 explicitly mentioned districts out of the total number 79. At the same time, the declared state of emergency in the respective territories concerned only explicitly identified entities, namely the specified healthcare providers.

Resolution of the Government of the SR No. 115 of 18 March 2020 (No. 49/20 Coll.) approved a proposal to extend both the declared state of emergency to the entire territory of the SR and the imposition of work duties to ensure healthcare. It also extended the ban on exercising the right to strike to certain workers declared by the Resolution of the Government No. 114 of 15 March 2020.

Resolution of the Government No. 72/2020 Coll. was effective from April 8, 2020 to April 13, 2020 and limited temporarily (during the Easter holidays when residents increasingly travel and meet indoors) freedom of movement and stay by curfew, but its application was limited by numerous and confusing exceptions. At the same time, a ban was imposed on the exercise of the right to peaceful assembly, with the exception of persons living in the same household, but without a defined time limit.

On March 27, 2020, the Government approved, by Resolution No. 169, the extension of the state of emergency pursuant to Article 5 par. 3 letter b) of the Constitutional Act No. 227/2002 Coll. on the imposition of an employment obligation to ensure the provision of healthcare within the scope of nursing care in residential facilities of social services, which are facilities for the elderly, care facilities, social service homes, specialized facilities, in social protection facilities for 
children and social guardianship, which are centers for children and families and the extension of the ban on exercising the right to strike under Article 5 par. 3 subpar. k) to workers in these facilities.

The Government continued to invoke its constitutional competence to issue legal acts in the form of by-laws - government regulations, which are published in the state official gazette - Collection of Laws. The Government Regulation No. 80/2020 Coll. of April 14, 2020, which extended the temporary reintroduction of border control at the internal borders of the SR, was adopted pursuant to $₫ 13$ par. 1 of the Act No. 404/2011 Coll. on the stay of foreigners and on amendments and supplements to certain acts. From April 18, 2020 to May 7, 2020, the reintroduction of border control at the internal borders of the SR with the Republic of Austria, Hungary, the Czech Republic and the Republic of Poland and at international airports was extended, with border crossings limited to specified times as stated in the attachment.

By Resolution No. 366, the Government repealed the employment obligation to ensure the provision of healthcare, the ban on exercising the right to strike imposed in relation to the entities listed in the annex to the Resolution No. 115 of March 18, 2020 and extended by the Resolution No. 169 of March 27, 2020 by the Resolution No. 233 of April 16, 2020 and the prohibition of exercising the right to peaceful assembly, by declaring the Resolution No. 366 in the Collection of Laws, i.e. from June 10, 2020.

\subsection{Problem fields}

Parliamentary control over emergency measures adopted by the Government represented the application of general control mechanisms under the Constitution of the SR (1992), such as the obligation of the prime minister and the Government to account for their activities before Parliament and to reply to inquiries or questions submitted to them by members of Parliament; work by parliamentary committees and ad hoc inquiry committees to scrutinize government actions; and, the possibility of expressing distrust to the Government or a member of the Government and proposing their dismissal. Given the focus of our study, we will not deal further with those particular matters. 
According to Svák (2020), practical experience with the declaration of a state of emergency, with the adoption of measures in its regime, their nature and especially their duration, justifies a change in the constitutional regulation of a state of emergency. According to him, the subject of such a change should be stricter conditions for its promulgation and duration, but also the establishment of rules and responsibility for their constant review in terms of their duration and justification of their application.

The amendment to the Constitutional Act on State Security, effective from December 29, 2020, introduced changes that define the scope of interference with fundamental rights and freedoms due to a pandemic, and are significantly narrower than we have already mentioned above. Nevertheless, as highlighted by Vernarec \& Piešt'anský (2020), it is necessary to consider the adequacy and implementation of the division of competences between public authorities in accordance with the Act No. 387/2002 Coll. on the mManagement of State in Crisis Situations outside the Time of War and State of War (the "Crisis Management Act"). The said Act regulates the activities of public authorities during a state of emergency, and provides a procedure for resolving a crisis situation, which is, inter alia, a state of emergency, and defines crisis management bodies. These include Pursuant to $\ 3$ : "the Government, ministries and other central state administration bodies, the National Bank of Slovakia , the regional security council, the district office at the regional seat, the district office, the district security council and the municipality". The PHASR is not a central body of state administration (although it has competence throughout the territory of the SR), and therefore it is not a body of crisis management - it is the MHSR and the Government of the SR, which have the authority to issue measures. The Crisis Management Act thus recognizes the possibility of issuing measures to high public authorities (which are bodies hierarchically above the PHASR), which may have their content overlaps with the PHA Measures issued pursuant to Article $\int 48$ par. 4 of the PHA (Vernarec \& Piešt’anský, 2020). The regulatory powers of executive bodies should be clearly differentiated, to avoid doubts about their legality - one of the pillars of the rule of law. 


\section{$4 \quad$ Legal acts issued by the National Public Health Authority}

In connection with COVID-19, the PHASR ordered measures with a nationwide scope, which applied to an indefinite number of entities, from the beginning of March 2020. The first measures, issued from March 9 to March 12, 2020, took the form of decisions issued in administrative proceedings pursuant to the Administrative Procedure Code. Subsequent measures took the form of generally binding legislation, or the so-called hybrid legal acts. Despite the fact that the legal order of the SR does not formally define hybrid legal acts, these occur in our legal system, as confirmed by the Constitutional Court of the Slovak Republic in its decision of 2009. From a theoretical point of view, mixed legal acts have the character of a hybrid between a decision and a secondary legislation. (Baricová et al., 2018: 36-37). Measures taken by the PHASR represent a legal act, the subject of which are determined specifically (for example, the regulation of the obligation to cover the upper respiratory tract), but the addressee is general and therefore not specific (Vernarec \& Piešt’anský, 2020).

The legal form and content of these PHASR decisions/measures have been the subject of criticism by not only the professional public from legal practice as well as from the academic community, but also by specialist state bodies. As pointed out by Vernarec \& Piešt'anský (2020), the measures instituted between March 6 and March 12, 2020, were issued pursuant to par. $\ 48$ par. 4 letter e) of the Public Health Act, in the form of decisions pursuant to the Administrative Procedure Code, and included information on the parties they applied to and information on the possibility of lodging an appeal. Measures from March 12, 2020, onwards were issued by the PHASR as the competent state administration body in the field of public healthcare pursuant to $\ 5$ para. 4 letter h) of Act No. 355/2007 Coll. on protection, support and development of public health due to the declaration of an emergency situation in the territory of the Slovak Republic by the Resolution of the Government of the Slovak Republic No. 111 from March 11, 2020 to March 12, 2020, from 6:00 am and the COVID-19 pandemic declared on March 11, 2020, by the Director-General of the World Health Organization. When creating regulations, the PHASR proceeded in accordance with $\ 48$ par. 4 letter e) of the Act No. $355 / 2007$ Coll. However, they were not published in any official journal of laws, but merely in the web page of the PHASR. (Vernarec \& Piešt'anský, 2020) 
On May 21, 2020, the amendment No. 125/2020 to the Act No. 355/2007 on public health came into force. It stated that all subjects have a legal duty to act in accordance with the "Measures in Terms of Public Health Threat issued by the Public Health Authority". An example of such measure is the Measure of Public Health Authority in Case of Public Health Thread No. OLP/6911/2020 from August 28, 2020. Since September 1, 2020, PHASR imposed an obligation upon employers to control the duties of their employees using measures of home quarantine and testing. The employer has a duty to ask each employee to show a certificate about staying in home quarantine and a negative result of RT-PCR on COVID-19 in situations where the employer has knowledge and reasonable suspicion that the employee had been abroad during the previous 14 days and any of the defined exemptions are applicable in terms of Measure of the Public Health Authority in Case of Public Health Thread No. OLP/6850/2020. Additionally, the employee also has a duty to register when crossing borders into the SR and to show to the employer that he or she did not cross the border in the last 10 days, depending on the country from which he or she came, with some exemptions (for example, for people who live near the borderline and work across the border). In cases where an employee does not have the abovementioned documents, or refuses to show them to the employer, the employer has a new obligation: 1 . to report this event to a regional office of the public health authority, and 2. to deny the employee entrance to any of the employer's workplaces or facilities. Based on $\ 56$ section 2 of the PHA, an employee can be sanctioned for a misdemeanor up to 1,659 EUR. If an employer fails to meet the above-mentioned duties, the liability for an administrative tort can be applied and the employer can face a financial sanction up to 20,000 EUR.

As PHASR is a specialist governmental state-funded agency having a lower status in the hierarchy of central state bodies, the General Prosecutor Deputy, Viera Kováciková, argued before the Constitutional Court of the SR in August 2020 that the PHASR lacked sufficient legal status to issue the Regulation entitlted „Measures"and that accordingly the Regulation was unlawful. It was only on October 15, 2020, that the Parliament passed the Act No. 286/2020 Coll. amending the Act No. 355/2007 Coll. on Public Health - to strengthen the powers of PHASR and its regional offices in creation of regulatory framework, allowed them to adopt "Decrees" instead of "Measures", requiring their publication in the official journal "Collection of Decrees of the Government of the Slovak Republic" which is available on the website of the Ministry of the Interior of the SR. 
On February 10, 2021, the Public Defender of Rights (Ombudswoman) petitioned the Constitutional Court of the SR in connection with the alleged violation of fundamental rights and freedoms of citizens during a pandemic, challenging especially the ambiguity of competencies in the field of interference with people's personal freedom in the form of isolation or quarantine in the context of a pandemic. (The State asked inappropriately high prices from isolated people to refund their stay in the State quarantine facilities during the 1st „wave“ of COVID-19).

Moreover, the head of PHASR used its wide competencies and granted more than 8,880 individual exemptions from isolation and quarantine between March and December 2020, in accordance with law. The procedure required just a simple formal request of any of the government members. (PHASR, 2021)

All of the above-mentioned issues, together with the high frequency of changes of the measures issued by the PHASR, could have an impact on „pandemic fatigue,..

\section{Core measures during the first vs. the second "wave" of COVID-19 pandemic}

Parliament's legislative activity in response to the COVID-19 pandemic led to the adoption of several important laws aimed at preventing the complete paralysis of society and modifying the way in which the rights and freedoms of natural and legal persons as well as public authorities are exercised (such as access to courts, employment protection) and at the same time enabling the implementation of measures to limit the spread of SARS-Cov-2 (for example acts No. 62/2020, 63/2020, 66/2020, 125/2020, 445/2020). Pursuant to Act No. 63/2020 Coll. titled "Act amending the Act No. 461/2003 Coll. on Social Insurance, as amended, and amending certain acts", the legal institute of sickness benefit/allowances has been modified to deal with situations where a person insured against sickness has been quarantined or isolated in connection with measures against the spread of COVID19. Act No. 66/2020 Coll. "on emergency measures in connection with the spread of dangerous infectious human disease COVID-19 in the field of healthcare, and supplementing and amending certain acts" enacted, stipulates that providers of healthcare will not be liable for damage caused to the patient due to insufficient personnel or material equipment of the medical facility, if those circumstances are causally related to the declared state of emergency. The Act 66/2020 Coll. also 
regulates the list of works for which the use of personal protective equipment is necessary due to the protection of life and health of employees and enabled the MHSR to prohibit the export of personal protective equipment abroad. It also amended the Labor Code.

The combination of legitimate interests of various subjects was very challenging and has polarized society, in particular the part of the population who did not feel directly at risk from COVID-19. The majority of anti-pandemic measures were adopted by the Government and the PHASR. Because of their wide scope and limited extent of this paper, the authors provide just a brief overview.

Slovakia experienced the so-called "1st wave" in spring 2020, with a total of 33 deaths. New regulations prioritized public health, with rather good compliance from inhabitants. The early emergency legal response in March 2020 included restrictions upon health care services (postponing of planned health care, check-ups and unnecessary diagnostics). Most of the legislative measures focused on the isolation of individuals and changing the behavior of individuals as regards their health, and imposing preventive measures to hamper the spread of the contagious disease. These measures included, for example, the requirement of wearing face masks, the identification and isolation of those who were considered to be sources of contagion and their contacts (as identified by epidemiological tracking by the public health authorities), curfews, teleworking, home schooling of pupils/distant learning between March 12 and June 13, 2020, the closure of churches and of non-essential services and retail, limiting time for shopping with priority hours for the older population, the evacuation of Slovak citizens from abroad and putting them in quarantine, limiting cross-border transit, the compulsory quarantine of incomers, etc. The majority of cases in Slovakia were "imported" - closing of state borders was helpful. Community spreading was controlled through measures limiting the mobility of the population. The ability of public health offices to effectively track the contacts of the infected individuals coupled with the willingness of the majority of Slovakia's population to adhere to unpopular restrictions and accept the curfew were important tools in limiting the spread of the virus. However, a negative consequence of the imposed restrictions was that many Slovakian families experienced financial hardships as well as an inability to meet the educational needs of their children. Most of the deaths in this wave were due to contagion of the vulnerable, elderly population residing in social care facilities. A relaxation of 
restrictions was related to the decrease of incidence of COVID-19 during May and June 2020. Starting in July 2020, Slovakian national borders were opened again.

Because of the exponential growth of the incidence rates once again in September 2020, the public health experts identified the so-called "second wave" of the virus. The Slovakian Government again was compelled to institute measures striking an appropriate balance between protecting both human and economic life. Thus, various anti-pandemic measures were once again instituted. These measures were supposed to help delay the introduction of a national curfew. These measures included, for example, restrictions on the number of people allowed at events, limitations on the freedom of movement for those not having a certificate confirming either the negative results of antigen testing or COVID-19 recovery, the closure of all non-essential services and retail (such as clothing), closure of restaurants and allowing only food takeaways and deliveries, and, mandatory home office work wherever possible. Personal capacities to track contacts of the infected were ineffective. Other ways of detectiing the infected individuals had to be developed. Any person meeting the criteria of a "suspected case" was required to be tested in a laboratory for SARS-CoV-2 as a part of an active case search. The State covered two PCR diagnostic tests a month per person, on the conditions these were prescribed by either a medical doctor or a public health official, and then only if there was a suspicion of infection (according to the criteria specified in the clinical testing protocol issued by the National Crisis Clinical Team). If a PCR test had to be performed for other reasons, it was classified as "on-demand" and the subject of private payments. In the period following the declaration of a state of emergency in October 2020, a curfew with many exemptions was introduced, as was the voluntary free of charge antigen testing as an exemption to quarantine. However, during this time the Government was not able to effectively control compliance with the quarantine measures. Efforts were undertaken to monitor the movement of people using citizens' data collected by telecommunications operators. Since October 2020, secondary schools were closed and since October 26, also the 2nd grade of elementary schools were closed. Thousands of children had limited access to primary and vocational education for most of the year 2020 and beyond. Since January 1, 2021, churches were closed and in March 2021, a former European Commissioner, J. Figel', turned to the European Court of Human Rights and also to the General Prosecutor claiming that the State unlawfully restricted collective exercise of the right on religious freedom by banning religious services during emergency. Since 
November 2020, the Government attempted to work with the various constituents to find consensus about the alert system („COVID automat") in order to differentiate the level of restrictions based on differences in the epidemiological situations regionally. Legislation finally passed in February 2021. Since December 26, 2020, there has been a roll-out of EMA-registered vaccines. These vaccines are distributed to priority groups free of charge, on a voluntary basis. As the mortality rates due to COVID-19 disease grew enormously during the winter, and further restrictions trying to reduce interpersonal interaction were imposed, Slovakian society became more deeply polarized, suggesting a "pandemic fatigue" and frustration.

\section{Criminal Aspects of Anti-pandemic Measures}

In the SR, COVID-19 disease falls under the legal definition of a dangerous, contagious human disease. Criminal sanctions for the dissemination of SARS-Cov2 belong in the category of the extreme means of protection of society in the SR. This is the case because criminal law is a means of ultima ratio and occurs only in cases where protection by other legal means is not sufficient. This is also the primary reason why, in concrete practice, most violations of anti-pandemic measures are not punishable by criminal law. In truth, however, given the lax and often even negative attitude of the public to comply with anti-pandemic measures, in our judgment it would be appropriate for law enforcement authorities to apply the relevant facts of the offenses more rigorously. The most common cases of violations of antipandemic measures are non-coverage of the upper respiratory tract (i.e. the failure to use either face masks or similar face covering devices) and non-compliance with quarantine or other restrictions on contact with humans.

The criminal sanction for the spread of SARS-Cov-2 is implemented primarily by the application of the threatening criminal offense of "spreading a dangerous contagious human disease".This offense may constitute an intentional criminal offense regulated according to $\ 163$ of Act No. 300/2005 Coll. of the Criminal Code, as amended (hereinafter referred to as the "Criminal Code"). Or, pursuant to Section 164 of the Criminal Code, also it can constitute a negligent criminal offense.. This means 1) the victim of the offence is either infected but without significant deterioration of health, or 2) the victim of the offence is not infected by the virus but it is sufficient that the perpetrator behaved in such a way as to expose him to 
the possibility of contagion (for example, a visit in violation of quarantine). If the criminal offense in question results in serious injury or death (death must be caused by negligence, otherwise it would be murder), the offender commits a qualified offense, either according to $₫ 163$ par. 3 letter a) or according to $\ 164$ par. 2 letter b) of the Criminal Code. In the case of a less serious consequence in the form of injury to health, this will be considered a concurrence of the basic factual basis of the "spread of a dangerous contagious human disease" together with the crime of "injury to health" in a less severe form. From a procedural point of view, for a completed offense of "spreading a dangerous contagious human disease" to have been committed, the offender is either required to be infected with the virus personally or to have handled it in an unsafe manner (for example, the unprofessional handling of virus samples). In the case of an intentional form of this crime, it is also possible to infer criminal responsibility for the attempted crime.

In the case of the restrictions to which they are subject, people often like to argue about the importance of their own human rights and freedoms, but forget that in a civilized society they are also obliged to behave in such a way that their behavior does not endanger and violate the freedoms and rights of others, which undoubtedly include the right to life and the right to health.

Problems stemming from non-compliance with anti-pandemic measures were not unique to Slovakia, but rather constitute a global problem, intensively experienced especially in developed democracies. However, the questions remain - if we have consistently penalized criminally relevant violations of anti-pandemic measures:

- Wouldn't too many innocent people have been punished so far?

- Is this even possible, given that the representatives of law enforcement agencies or courts are only human, and there are also many ignorant antipandemic measures among them?

- In difficult times, people radicalize and like to defend themselves against things they don't like and against the authorities that enforce them. So, could the enactment of criminal sanctions for breaches of anti-pandemic measures only serve to heighten public opposition to politicians and other professions responsible for managing the fight against a pandemic? 
Verifying the answers to these questions in practice could be a very dangerous experiment.

\section{$7 \quad$ Rule of Law and the Pandemic}

A very important requirement imposed on the State authorities, which should be fulfilled even in times of crisis, such as the one caused by the COVID-19 pandemic, is the protection of the population against the abuse of State power against its citizens, and the obligation not to impose legislation that unfairly and unjustifiably works to the disadvantage of certain social or population groups while benefitting other citizens. These requirements comprise part of the rule of law doctrine, the application of which is linked to the human rights value base it is intended to protect.

The Slovak Republic is a signatory to all major international agreements in the field of health protection of individuals, or public health. It is a member of the Council of Europe and since May 1, 2004 also of the EU. The Council of Europe Convention for the Protection of Human Rights and Fundamental Freedoms (Communication of Federal Ministry of Foreign Affairs No. 209/1992 Coll.) regulates the right to respect private and family life in (1992, Article 8) and "a public authority may not interfere with the exercise of this right unless it is lawful and necessary in a democratic society in the interests of national security, public security, the economic well-being of the country, the prevention of riots and crime, the protection of health or morals or the protection of human rights, freedoms of others." (1992, para. 2) The European Social Charter (revised) (Communication of Ministry of Foreign Affairs No. 273/2009 Coll., Article 11), states: "In order to ensure the effective exercise of the right to health, the Contracting Parties undertake to take appropriate measures, either directly or in cooperation with public or private organizations, which shall, inter alia:

1. eliminate, if possible, the causes of deteriorating health,

2. provide counselling and educational services to promote health and personal development responsibilities in health matters,

3. prevent, as far as possible, epidemic, endemic and other diseases, and accidents." 
In this sense, it is the State's duty to exercise its power in such a way that known determinants of health are controlled; on the one hand to limit the influence of factors that harm human health, on the other hand to implement measures that have a beneficial effect on health. This obligation requires the development of an effective institutional framework, state bodies that work effectively and efficiently, and also the enactment of regulations governing human behavior in various everyday situations. Developing adequate legal responses to effectively deal with health determinants and threats, especially to the pandemic, thus transcends the "traditional" branches of law and calls for transdisciplinary scholarship.

The phrase "Rule of Law" is "one of the ideals of our political morality and it refers to the ascendancy of law as such and of the institutions of the legal system in an overarching system of governance." (Waldron, 2020) The concept of Rule of Law has been discussed and explored by many legal theorists and philosophers. A "checklist" of empirical indicators was developed by the Venice Commission in 2016. In general, "the Rule of Law comprises a number of principles of a formal and procedural character, addressing the way in which a community is governed. The formal principles concern the generality, clarity, publicity, stability, and prospectivity of the norms that govern a society. The procedural principles concern the processes by which these norms are administered, and the institutions - like courts and independent judiciary - that their administration requires". (Waldron, 2020)

As Waldron highlighted, "it is often thought that emergencies require forms of State action that are more peremptory and less procedurally laborious than those required in normal times, and modalities of application of rule of law can occur:

1) One is to insist, in the name of the Rule of Law, that existing constitutional safeguards should remain in force; that, after all, is what they were designed for and these situations are where they are most urgently needed.

2) Alternatively, in emergencies, one might rely on a general spirit of flexibility and circumstantial sensitivity in State action that is encouraged even in normal times. On this second option, the Rule of Law does not present itself as a major constraint on the flexibility of State action in face of danger.

3) As a third option, one might seek to preserve something like the Rule of Law by laying down in advance specific legal rules to govern emergenciesrules that suspend ordinary civil liberties guarantees, for example, or 
authorize widespread discretion on the part of officials to undertake action that would normally be governed by general rules of law. This option has the advantage of predictability; but its disadvantage is that it endorses a sort of Rule-of-Law-lite, which may eventually infect or supersede the conception of the Rule of Law that is supposed to be normally applicable" (Waldron, 2020).

The most important demand of the Rule of Law, according to Waldron (2020), is that people in positions of authority should exercise their power within a constraining framework of well-established public norms rather than in an arbitrary, ad hoc, or purely discretionary manner on the basis of their own preferences or ideology. It insists that the Government should operate within a framework of law in everything it does, and that it should be accountable through law when there is a suggestion of unauthorized action by those in power. "But the Rule of Law is not just about Government, rather, it is about primacy of law" - as highlighted by Waldron (2020), rule of law requires also that citizens should respect and comply with legal norms, even when they disagree with them - when their interests conflict with others, they should accept legal determinations of what their rights and duties are. In our opinion, this aspect of rule of law is very important and can make implementation of anti-pandemic measures a real problem, if the measures are perceived as an "oppression" by the inhabitants.

Also, the law should be the same for everyone, so that no one is above the law, and everyone has access to the law's protection. This requirement of access Waldron (2020) explains in two senses: "First, law should be epistemically accessible: it should be a body of norms promulgated as public knowledge so that people can study it, internalize it, figure out what it requires of them, and use it as a framework for their plans and expectations and for settling their disputes with others. Secondly, legal institutions and their procedures should be available to ordinary people to uphold their rights, settle their disputes, and protect them against abuses of public and private power."

Current challenges for the rule of law in times of pandemic include the issue of flexibility, legality and proportionality of measures, but also the issue of the effectiveness of law and need to consider social functions of law and not just "instrumental" public health functions of law in legal response to the pandemic. 


\section{Conclusion}

The current pandemic has given rise to very complex problems, for which quick and easy solutions are not available. The role of public health measures is to reduce adverse effects of the pandemic on human life and health. Siracusa principles (ICJ, 1984) enable governments' obligations to find the least restrictive options for limiting human rights and freedoms under justified circumstances.

As outlined in previous chapters, since the outbreak of the COVID-19 disease in Slovakia, the most significant problem fields in the regulatory framework can be identified as follows: 1 / The legality and hierarchy of measures limiting everyday life and the exercise of citizens' rights and freedoms; 2/ the scope, proportionality, extent and duration of anti-pandemic measures and their corrections; $3 /$ problems associated with adherence to the measures by the public and law enforcement. However, standards and warranties of human rights protection are implemented into the national legislation and served as important safeguards of public health interventions.

The pandemic had a significant impact on the institutional and legal framework in Slovakia in the studied period (March 6, 2020 - March 15 2021). The constitutional law on the state of emergency was amended and mechanisms for the extension of the state of emergency have been made more flexible, while the controlling powers of the Parliament have been preserved. The powers of the Public Health Authority have been broadened by the statutory law, and the legal status of the bylaws (called "measures") this State agency issues have been strengthened, but doubts about their legality persist. However attractive and useful it may appear at first glance to have a unified, strong public authority to achieve flexible regulatory response to the public health emergency, there is still a high risk of unintentional mistakes, of political influences on its decision making and use of its powers, or of the inefficiency of measures it introduces. Public health law and policy to control possible future crises must be based on the rule of law principles, with various procedural and institutional mechanisms of flexible control exercised over the powers wielded by public bodies (for example, revision of decision to close all small retail shops which negatively affected basic needs of people). In Slovakia, for example, courts, the Constitutional Court, the General Prosecutor and the Public Defender of Rights were engaged in the revisions to or legality checks of anti-pandemic measures. 
Some more critical points and recommedations could be formulated, to assist in the navigation of public health law and to better inform policy makers in the future. First, efforts to control the spread of virus by means of legal acts and bylaws issued of the executive bodies (such as Resolutions of Government, measures of the National Public Health Authority, Decisions of ministers) have made it possible to adopt measures and restrictions relatively quickly. The downside, or negative consequences associated with this is that these laws were adopted by the executive bodies and due to the complexity of the legal and technical terminology used in them, and the fact the conditions caused "on the ground" by the virus, far from being static, evolved rapidly (seemingly every day ), led to constant changes to the measures which, in turn, caused a great deal of confusion and unpredictability for addressees, all of which is in contrast to usual rule of law requirements. The predictability of legal measures (certitudo iuris) affecting everyday life of people is an important factor that can increase the public's motivation to comply with the measures. Unfortunately, unpredictability often has the opposite impact on the public. Second, all-national restrictions of various fields of social life (for example, school attendance, access to primary health care, shopping of clothes and shoes) embodied in regulations and legislation should be exceptional and should remain effective for as short a period as possible. Otherwise, measures may fail to achieve adherence if inhabitants find them inappropriate. A "one-size-fits-all" approach should be applied only in cases where professionally defined criteria are met. Any measures should be adopted in a rule of law framework, in a transparent process, justified, and proportionate, based on the best available scientific evidence and discussed with experts with various professional backgrounds, not just physicians. Third, the role of expertise is very important in order to achieve the highest substantial and formal quality of measures. Again, experts other than only health professionals should participate. The "good will" on the part of the legislators or the executive bodies "to save lifes" cannot justify low quality bills and regulatory proposals, because this contradicts the rule of law. Fourth, declared emergency regimens cannot justify a truncated legislative process to address issues unrelated to whatever the current crisis situation (such as bills on restriction of abortions) happens to be and for which the state of national emergency was declared. Fifth, the regulatory powers of executive bodies should be clearly differentiated, to avoid doubts about their legality. Next, measures and their rationale should be clearly communicated to the public and to specific target groups in accordance with the principles of legal communication and public health communication (see for 
example, WHO, 2017) and not according to the lessons of political marketing. More recommendations can be formulated, but especially, the transdiciplinary nature of public health interventions and necessity of multiprofessional and multisectoral collaboration should be highlighted.

\section{Acknowledgments}

The authors declare no conflict of interests. The authors also would like to thank the editors of the journal and to the anonymous reviewers for their helpful comments and suggestions.

\section{Notes}

Extraordinary situation related to COVID-19 in Slovakia announced under Act on Civil Protection (1994) by the Goverment, valid since March 12, 2020 was not repealed until the day of the submission of this manuscript.

\section{Legislation, Acts, Regulations or Court Decisions}

Act No 355/2007 Coll. on protection, promotion and support of public health ("Act on Public Health"), as amended.

Act No. 125/2020 amending Act No 355/2007 on public health.

Act No. 125/2020 amending Act No. 355/2007 Collection of Laws of the Slovak Republic (hereinafter referred as "Coll"«) on public health.

Act No. 179/2011 Coll. on Economic Mobilization, as amended.

Act No. 300/20005 Coll. The Criminal Code, as amended.

Act No. 311/2001 Coll. The Labour Code, as amended.

Act No. 387/2002 Coll. on the management of state in crisis situations outside the time of war and state of war (the "Crisis Management Act"), as amended.

Act No. 42/1994 Coll. on Civil Protection, as amended.

Act No. 45/2011 Coll. on Critical Infrastructure, as amended.

Act No. 460/1992 Coll. The Constitution of the Slovak Republic, as amended.

Act No. 62/2020 Coll. on certain emergency measures in relation to the spread of the dangerous contagious human disease COVID-19 and in the judiciary and amending certain acts.

Act No. 63/2020 Coll. Act amending the Act No. 461/2003 Coll. on Social Insurance.

Act No. 66/2020 Coll. on emergency measures in connection with the spread of dangerous infectious human disease COVID-19 in the field of healthcare and amending certain acts.

Act No. 69/2020 Coll. on emergency measures related to rapidly spreading dangerous contagious human disease COVID-19 in field of health care and amending some acts,

Constitutional Act No. 227/2002 Coll. on security of the state at time of war, state of war, state of emergency (the "state Security Act"), as amended.

Constitutional Act No. 414/2020 Coll. amending the Constitutional Act No. 227/2002 Coll.

Convention for the Protection of Human Rights and Fundamental Freedoms. Council of Europe. Communication of Federal Ministry of Foreign Affairs, No. 209/1992 Coll.

Decree of Ministry of Health No. 585/2008 Coll. laying down details on the prevention and control of communicable diseases, as amended.

European Social Charter (revised). Communication of Ministry of Foreign Affairs, No. 273/2009 Coll.

World Health Organization. (2017) Communicating risk in public health emergencies: a WHO guideline for emergency risk communication (ERC) policy and practice. $57 \mathrm{p}$. Geneva: World Health Organization. https://apps.who.int/iris/handle/10665/259807 (20 February 2021). 
World Health Organization. (2020) Coronavirsus Disease (COVID-19): Events as they happen. Online: https://www.who.int/emergencies/diseases/novel-coronavirus-2019/events-asthey-happen_(20 February 2021).

\section{References}

Baricová, J., Fečík, M., Števček, M., Filová, A. et al. (2018) Správny súdny poriadok. Komentár (Bratislava: C. H. Beck), pp. $36-37$.

Chandogová, E. (2018) Zdravotnícky system, In: Ozorovský, v. a kol.: Sociálne lekárstvo, 2. extended ed. (Bratislava: AEP), pp. 103 - 133.

International Commission of Jurists (1984) Siracusa Principles on the Limitation and Derogation Provisions in the International Covenant on Civil and Political Rights, retrieved from: https://www.icj.org/wpcontent/uploads/1984/07/Siracusa-principles-ICCPR-legal-submission-1985-eng.pdf May 2021).

PHASR. (2021) Od apríla do decembra 2020 sme udelili vyše 8800 individuálnych výnimiek pre občanov (2. stanovisko ÚVZ SR k individuálnym výnimkám vo „vyhláške k hraniciam“). Press release. January 11., 2021, retrieved from:

https:/ / www.uvzsr.sk/index.php?option=com_content\&view $=$ article\&id=4580:od-aprilado-decembra-2020-sme-udelili-vye-8800-individualnych-vynimiek-pre-obanov-2-stanoviskouvz-sr-knindividualnym-vynimkam-vo-vyhlake-knhraniciam\&catid=56:tlaovespravy\&Itemid $=62$ (20 September 2021).

Svák, J. (2020) Ústavnost' mimoriadnych zákonov pre boj s Covid-19, In: Weyrovy dny právní teorie 2020 (Brno: Masarykova univerzita), pp. 8-24, retrieved from: https://science.law.muni.cz/knihy/Weyrovy_dny2020.pdf (20 February 2021).

Škrobák, J. (2020) Správne právo v časoch pandémie koronavírusu. Čast' prvá: Núdzový stav(?), ComenIUS blog, March 15, 2020, retrieved from: https://comeniusblog.flaw.uniba.sk/2020/03/15/spravne-pravo-v-casoch-pandemiekoronavirusu-cast-prva-nudzovy-stav/ (20 February 2021).

Vernarec, P., \& Piešt’anský, J. (2020) Ako sa obrátit' na súd alebo k charakteru opatrení Úradu verejného zdravotníctva SR, Epravo, Jun 1, 2020, retrieved from: https://www.epravo.sk/top/clanky/ako-sa-obratit-na-sud-alebo-k-charakteru-opatreniuradu-verejneho-zdravotnictva-sr-4814.html (20 February 2021).

Waldron, J. (2020) The Rule of Law, In: Zalta, N. E. (ed.) The Stanford Encyclopedia of Philosophy, retrieved from: https://plato.stanford.edu/archives/sum2020/entries/rule-of-law/ (20 February 2021). 
